The JOURNAL of

THE INSTITUTE

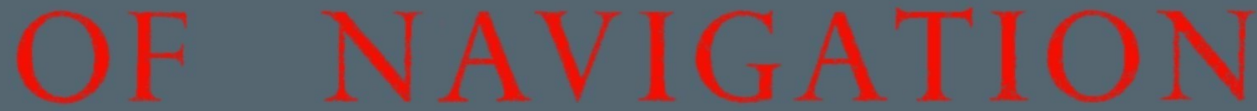

VOL. 2 I, NO. 2

APril

3968

The Reverse Stopping Ability of Supertankers

H. TAN

Handling Large Vessels in the Port of Hirohata

T. OxIshr

An Anti-collision lndicator

O. Mitrofanion

A Controlled Aximuth Avoidance Manceuvre

1) 3

R. N. LORD

Instrument Approach Criteria

I-Decision Height and RVR Minima

J. W. BLANCHARD

II-Autolanding and Safety

D. I. MAYES

11I-An Operator's Vicw

F. Ongonnoxo

Wind Variations along a Glide Path

T. W. HARROLD AND K. A. BROWNING

long-range Navigation Techniques for the S.S.T.

R. H. WALDMAN

\title{
FORUM
}

'Longitude without Time'

D. H. SADLER

Captain Flinders

R. ST. J, FancoukT

'The Metrication of Navigation '

D. H. SADLEB

Record

Reviews

242

Correspondence

THE INSTITUTE OF NAVIGATION

AI THE ROYAL GEOGRAPHICAL SOCIETY I KENSINGTON GORE LONDON SW 7

JOHN MURRAY (PUBLISHERS) LTD., 50 AI BEMARLE STREET, LONDON w 


\title{
THE INSTITUTE OF NAVIGATION
}

\author{
Patron \\ H.R.H. THE PRINCE PHILIP, DUKE OF EDINBURGH, k.G., k.T.
}

\section{OFFICERS AND COUNCIL $1967-8$}

\author{
President \\ Professor A. Stratton \\ Vice-Presidents \\ Captain A. F. Dickson
}

Air Vice MarshaI D. C. McKinley, c.в.E., с.в., D.F.c., А.ғ.c.

Honorary Treasurer

Captain M. E. Butler Bowdon, O.B.e., R.N.

Chairman of the Technical Committec

G. E. Beck

Chairman of the Membership and Fellowship Committee

D. H. Sadler, O.B.E.

J. H. Beattic

Air Commodore D. Bower, O.B.E., A.F.C.

W. O. Broughton

Captain W. R. Colbeck, R.N.R. (Ret.).

Captain R. Hart, C.B.E., D.s.O., D.s.c., R.N. (Ret.).
Other Members of Council

F. A. Haworth

Captain G. A. B. King

Commander G. V. Parmiter, R.N. (Ret.).

Rear Admiral G. S. Ritchie, C.B., D.s.c.

H. E. Smith

\section{Executive Secretary: M. W. Richey \\ Deputy Secretary: Sqn. Ldr. K. H. Houghton, D.r.c.}

\section{The Journal of the Institute of Navigation}

THE Journal is published quarterly by the Institute and is edited by $M$. W. RiCHEY. It contains original papers contributing to the science of navigation, including those presented at meetings of the Institute together with the ensuing discussion. In addition the Journal includes a record of current navigational work, reviews of important books, and other matters of concern to those interested in navigation. The views expressed in the Journal are not necessarily those of the Institute, or of any organization or department to which the authors may belong. In the case of some papers Crown Copyright may be reserved.

The Journal is issued free to all members of the Institute. It is sold to the public at thirty shillings per copy or, by subscription, at one hundred and twenty-five shillings per annum (post free) and may be obtained through all booksellers and John Murray (Publishers) Ltd., 50 Albemarle Street, London Wr.

Contributions, which are welcomed from both members and non-members, should be addressed to the Editor.

Enquiries for advertising space should be addressed to the Institute offices.

The postal address of the Institute is:

The Institute of Navigation, ot The Royal Geographical Society, r Kensington Gore, London $\mathrm{SW}_{7}$. 


\section{You get a good deal from}

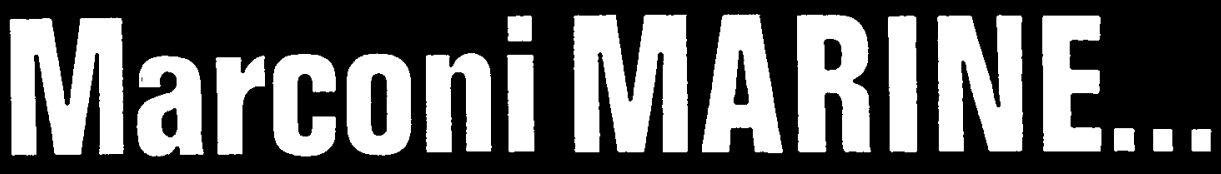

... let's deal with $\mathbf{R A D A R}$

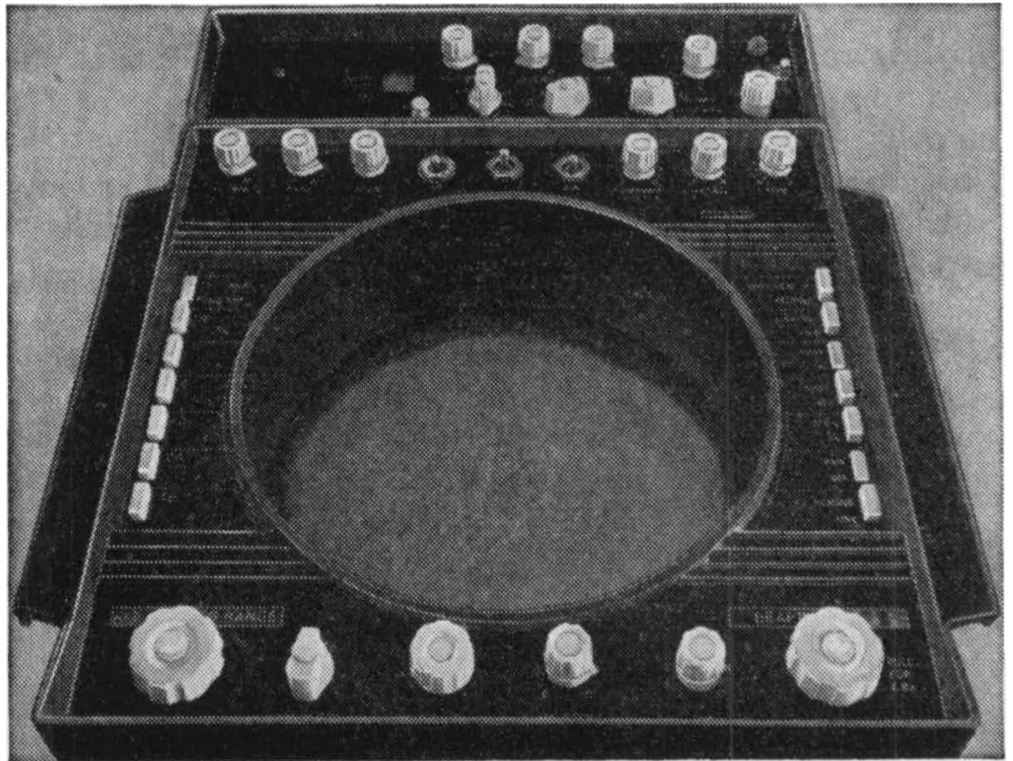

THE NEW 'RAYMARC' Series offers the finest radar value in the world. Choice of 12-inch or 16-inch displays, with or without true motion, or 12-inch high definition version for canal, river and harbour navigation.

Standard equipment includes variable range marker and electronic bearing indicator with digital readouts, performance monitor, visual tuning indicator and manual override of automatic pulse switching. Yet these new 'Raymarcs' cost less to buy, less to install, less to hire and maintain than any comparable radar. Make the cost comparison.

ALL AVAILABLE FOR OUTRIGHT SALE. ECONOMICAL RENTAL/MAINTENANCE TERMS IN THE U.K. AND MOST OTHER COUNTRIES

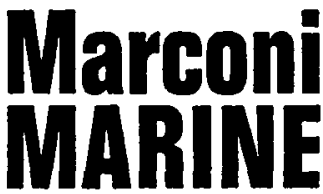

THE MARCONI INTERNATIONAL MARINE COMPANY LIMITED

ELETTRA HOUSE - WESTWAY - CHELMSFORD - ESSEX - TELEPHONE CHELMSFORD 57201 TELEX 99228, and at London and all principal ports 


\section{Marconi \\ complete \\ naval}

communications

A complete range of communications equipment using s.s.b, i.s.b and all other modes of h.f and m.f transmissions, designed specifically for naval communications systems.

- Simple, precise and highly accurate continuous decade selection of frequencies in $100 \mathrm{~Hz}$ steps.

- Rigid stability controlled by a single high accuracy frequency standard.
Extreme simplicity of operation com. bined with versatility of service and high quality performance.

- Synthesizers and wideband amplifiers employed in these systems, which make maximum use of semiconductors.

- NATO codified.

- Complete system planning and installation.

This new range of Marconi equipment has already been used in the modernization of the communications of 10 Navies.

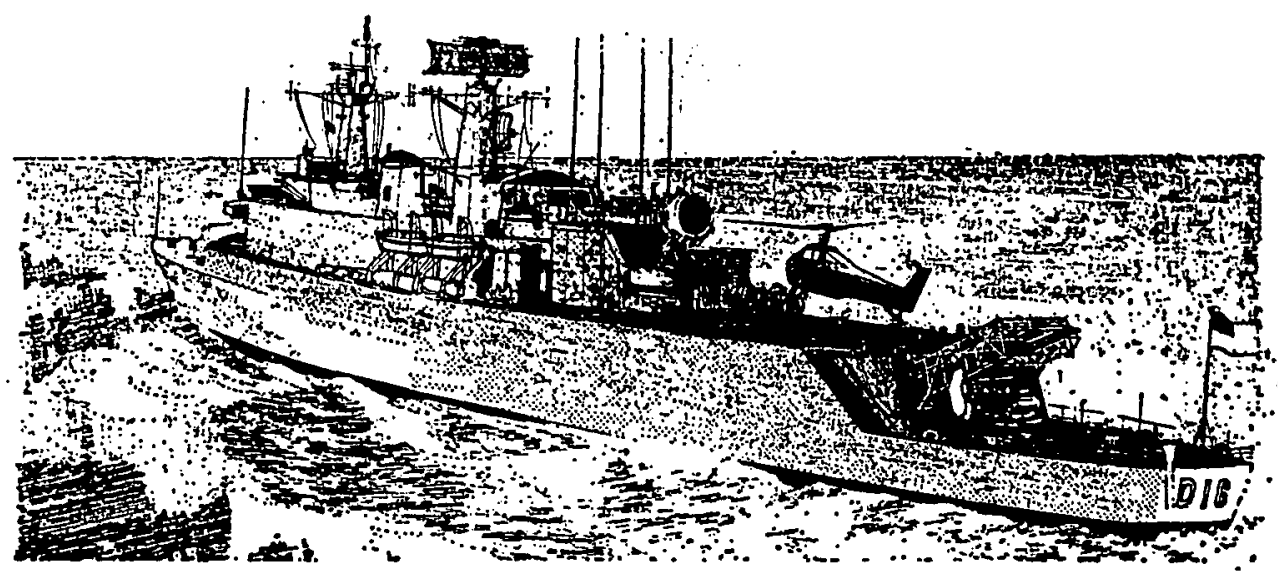

\section{Marconi naval radio and radar systems}

AN 'ENGLISH ELECTRIC' COMPANY

The Marconi Company Limited, Radio Communications Division, Chelmsford, Essex 


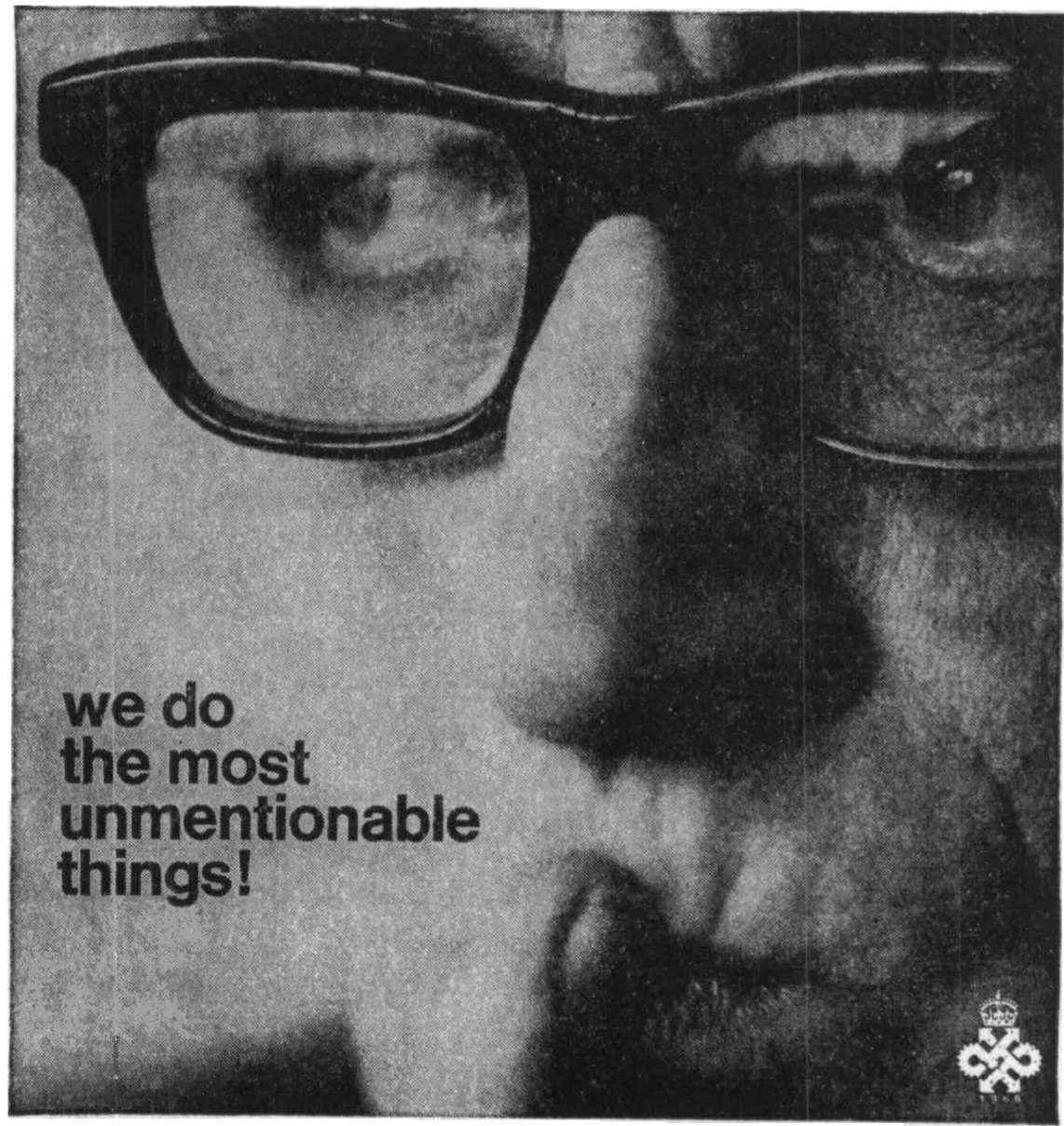

The accent throughout Smiths Industries Aviation Division is heavily on future flight requirements - confidential of course. But design secrets at Smiths Industries are frequently revealed as technological triumphs. For their research and development programmes they spend f $2 \frac{1}{2}$ million annually. Of the 5,000 personnel, in design trends. a quarter work solely on experimental projects in flight control, automatic landing, fuel gauging, and general instrumentation. Over 300 airlines and ail forces, all users of Smiths aviation equipment, constantly look to Smiths Industries Aviation Division for leadership

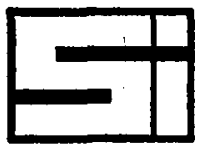

\section{SMITHS INDUSTAIES LIMITED}

\section{AVIATION DIVISION}

Kelvin House, Wembley Park Drive, Wembley, Middx.

Wembley 8888 Airspeed Wembley Telex 25366

Associated Companies in Toronto, New York, Sydney and Melbourne.

Flight control systems - General instruments and components - Fuel gauging equipment - Engine equipmeot 


\title{
Authoritative Sailing-Ship Books
}

\section{GOOLIE SHIPS AND OIL SAILERS}

This book is a record of two special phases of sea life in Sailing Ships

190 Pages $9 \frac{3}{4}^{\prime \prime} \times 7 \frac{1}{4}^{\prime \prime} \quad 56$ Illustrations

$30 /-$ (per post 34/6)

\section{THE COLONIAL GLIPPERS}

The Great Wooden Ships of the Blackwall and other lines

400 Pages $93^{\prime \prime} \times 74^{\prime \prime} \quad 81$ Illustrations, 4 Plans

$36 /$ (per post 40/6)

\section{THE GHINA GLIPPERS}

A History of the celebrated Clipper Ships in the Chinese Opium and Tea Trades 310 Pages $93^{\prime \prime} \times 7 t^{\prime \prime} \quad 34$ Illustrations

$36 /-$ (per post 40/6)

\section{THE LOG OF THE " GUTTY SARK"}

The most authentic work, compiled from her log books and captain's abstracts

344 Pages $93^{\prime \prime \prime} \times 7 \frac{1}{4}$ " 52 Illustrations, 9 Plans

45/- (per post 49/6)

\section{THE LAST OF THE WINDJAMMERS}

Vol. I. The Sailing Ships of the Seventies-Eighties

535 Pages $93^{\prime \prime} \times 71^{\prime \prime} 126$ Illustrations, 17 Plans

50/- (per post 54/6)

Vol. II. The Deep-Water Sailing Ships, 1888-1928

470 Pages $93^{\prime \prime} \times 74^{\prime \prime} \quad 174$ Illustrations, 17 Plans

50/- (per post 54/6)

By BASIL LUBBOCK

All Lubbock's work is the product of original and comprehensive research. These books are recommended without reserve to the student of the sailing-ship

\section{SAIL TRAINING AND GADET SHIPS}

This Magnificent Volume is a most complete record

366 Pages $9 \frac{3 "}{4} \times 7 t^{\prime \prime} \quad 132$ Illustrations, 45 Folding Plans

$60 /-$ (per post 64/6)

\section{DEEP.WATER SAIL}

For all Students of Sail and lovers of the Windjammer

387 Pages $93^{\prime \prime} \times 74^{\prime \prime} \quad$ Over 200 Illustrations, 28 Plates

60/- (per post 64/6)

\section{PLANK-ON-FRAME MODELS and Scale Masting and Rigging}

Vol. I. 38/- (per post 39/4) Vol. II. 34/- (per post 35/4)

\author{
BY HAROLD A. UNDERHILL
}

A leading authority on Sail and Ship Modelling

Catalogue " $N$ " giving further titles and details, free on request

\section{BROWN, SON \& FERGUSON, LTD.,}




\section{CRANFIELD \\ TRANSPORT STUDIES}

Postgraduate 1 and 2 year courses in Transportation Technology and Management combining studies in transport systems assessment with a specialist course selected from :

Aircraft project design; Air cushion vehicle design ;

Rotorcraft design; Rail vehicles;

Pipeline flows; Road vehicle engineering ;

Gas turbine propulsion ; Electrical propulsion ; Signalling, communication and traffic control ; Operational research; Transport management; Transport systems analysis.

The Science Research Council has accepted the Transportation Technology and Management courses as suitable for the tenure of its Advanced Course Studentships. The courses start in October, 1968.

Short Course in

Transport Systems Characteristics July 8th-19th, 1968.

A survey of modern transport techniques including Aircraft, Rail, A.C.V., Road, Ships and Transport Systems Analysis.

Residential course fee 75 guineas

Enquiries to: The Registrar,

The College of Aeronautics,

Cranfield,

Bedford. 


\section{The Institute of Navigation}

\section{INSTITUTE PUBLICATIONS}

\section{The Use of Radar at Sea}

A Handbook on Marine Radar. (New edition in preparation.)

\section{Observational Errors}

An elementary account of the ideas behind the statistical theory of errors, by E. W. Anderson \& J. B. Parker. (John Murray, 5s.)

\section{The Geometrical Seaman}

An illustrated work on early navigational instruments, by E. G. R. Taylor \& M. W. Richey. (Hollis \& Carter, 30s.)

\section{The Mathematical Practitioners of Tudor and Stuart England}

by E. G. R. Taylor. (Cambridge University Press, 70s. Members 55s. plus 2s. postage.)

An account of the ideas, instruments and methods in navigation and surveying between 1485 and 1715 with lists of the mathematical practitioners with biographical notes and details of their work.

\section{The Mathematical Practitioners of Hanoverian England}

by E. G. R. Taylor. (Cambridge University Press, 84s. Members 63s. plus 2s. postage.)

This book, a sequel to the earlier volume, takes the story up to $184^{\circ}$, by which time the independent mathematical practitioner had virtually disappeared, absorbed into the large firm or organization as a consequence of industrial and social change.

The Separation of Traffic at Sea

A Working Group Report

from The Institute of Navigation

I Kensington Gore, London SW, 


\section{'NAVIGATION, U.S.A.'}

Navigation, the quarterly Journal of the American Institute of Navigation, is available to members of thi Institute at a reduced subscription of $€ 1$ a year. Volume 14, No. 4 (Winter 1967) contains the following papers.

THE NAUTICAL ALMANAC IN ITS SEVENTH THIRD OF A CENTURY D. H. Sadler

MARINE NAVIGATION : WHERE WE STAND - WHAT NEBDS TO BE DONE G. D. Dunlap

NAVIGATION OF PLEASURB BOATS R. R. Blandford

NAVIGATION IN OCEAN SURVEYS Captain Miller Y. Tonkel, U.S.E.S.S.A.

ANALYSIS OF THE CELESTIAL PLOT IN MARINE NAVIGATION Emest B. Brown

NAVIGATION SATELLITES

Donald F. Spencer

GROUND-BASED RADIO AIDS TO NAVIGATION

Sven H. Dodington

NAVIGATION OF V/STOL AIRCRAFT IN HIGH-DENSITY URBAN AREAS

Tirey $K$. Vickers

NAVIGATION FOR GENERAL AVIATION

Glen $A$. Gilbert

SPACE NAVIGATION

William T. McDonald and Dr. Robert G. Stern

CURVES FOR LORAN-INERTIAL ANALYSIS

T. M. Pienkocoski

THE INSTITUTE'S PROFESSIONAL FILE

NOTBS AND COMMENT

Reviews of Recent Books

INDEX TO VOLUME 14 OF NAVIGATION

\section{ROYAL GEOGRAPHICAL SOCIETY}

\section{REPRODUCTIONS OF EARLY MAPS-VII}

\section{Early Maps of the British Isles}

\section{A.D. 1000 - A.D. 1579}

Collotype facsimiles of twenty manuscript and printed maps

with an Introduction and Notes by

G. R. Crone, M.A.

Librarian and Map Curator, R.G.S.

15 Collotype plates in a portfolio, $21^{\circ} \times 161^{\prime \prime}$.

The twenty maps, manuscript and printed, have been chosen to illustrate the development of the map of the British Isles from the Cotton world map of circa A.D. I000 to the general map in Christopher Saxton's county atlas of England and Wales, A.D. 1579. They thus extend from the earliest rudimentary manuscripts to the decorative printed maps of the Tudor period. Among the MSS. are several not hitherto generally available which have been included through the cooperation of the Trustees of the British Museum.

Price 35. plus postage: Inland $4 / 6$, Overseas according to dastination. 


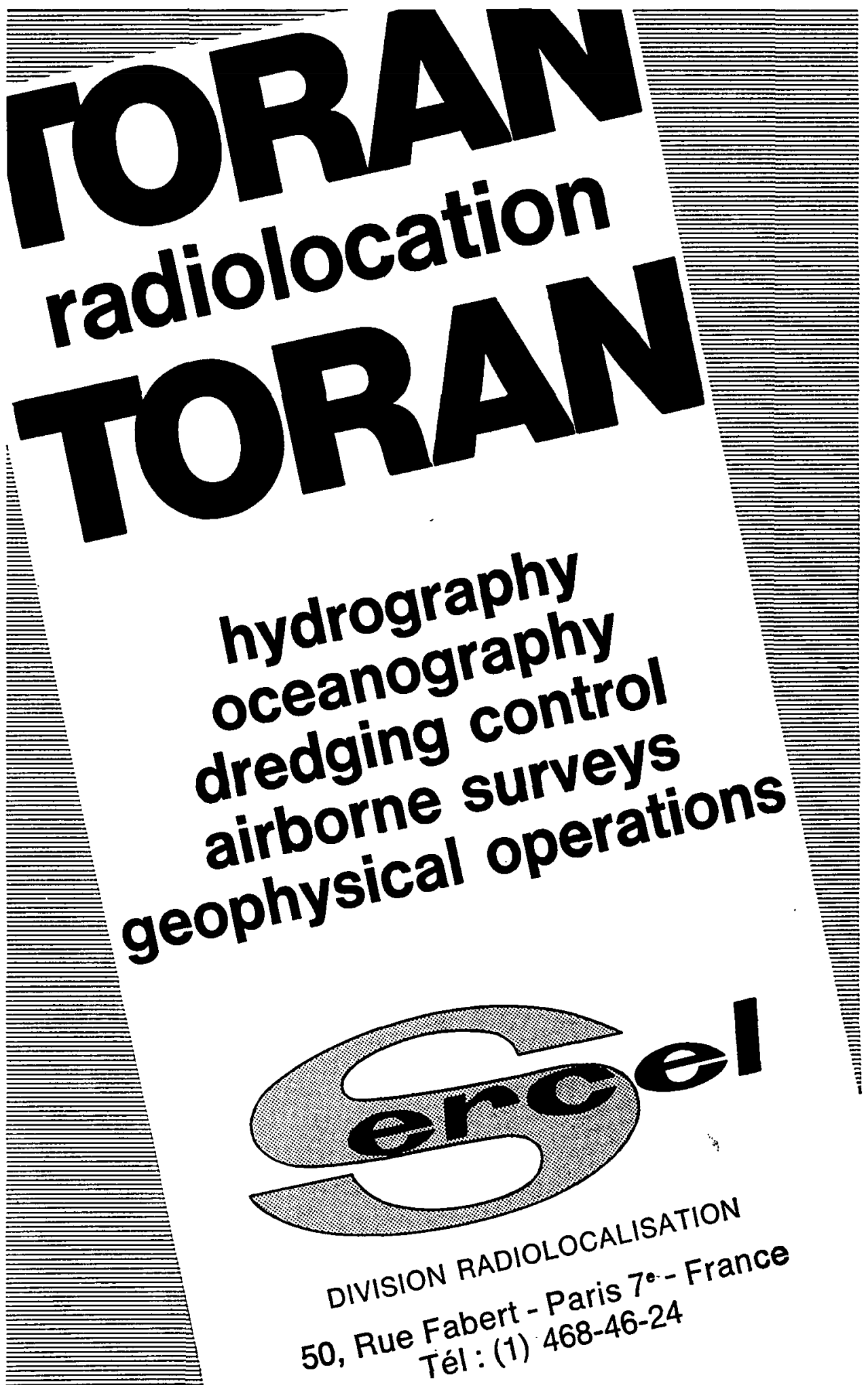




\title{
THE INTERNATIONAL HYDROGRAPHIC BUREAU
}

\section{Avenue Président J. F. Kennedy, MONACO}

\author{
publishes
}

twice a year, in January and July, an English and a French edition of

\section{THE INTERNATIONAL HYDROGRAPHIC REVIEW}

This publication contains articles of topical interest on hydrography, hydrographic surveying and related techniques.

Each volume contains an average of 160 pages, $18 \times 27 \mathrm{~cm}$., and numerous illustrations.

Price per number $\$ 5$ (U.S.) excluding postage.

Orders should be sent direct to the Bureau's Headquarters in Monaco, but payments can be made to the Bureau's account at Barclays Bank Ltd., Chief Foreign Branch, 168 Fenchurch Street, London, E.C.3.

A reduction of $30 \%$ on the price quoted is allowed to booksellers. The same reduction is granted to government offices and to naval or merchant marine officers of the Bureau's Member States, provided the order is sent direct to the Bureau. 


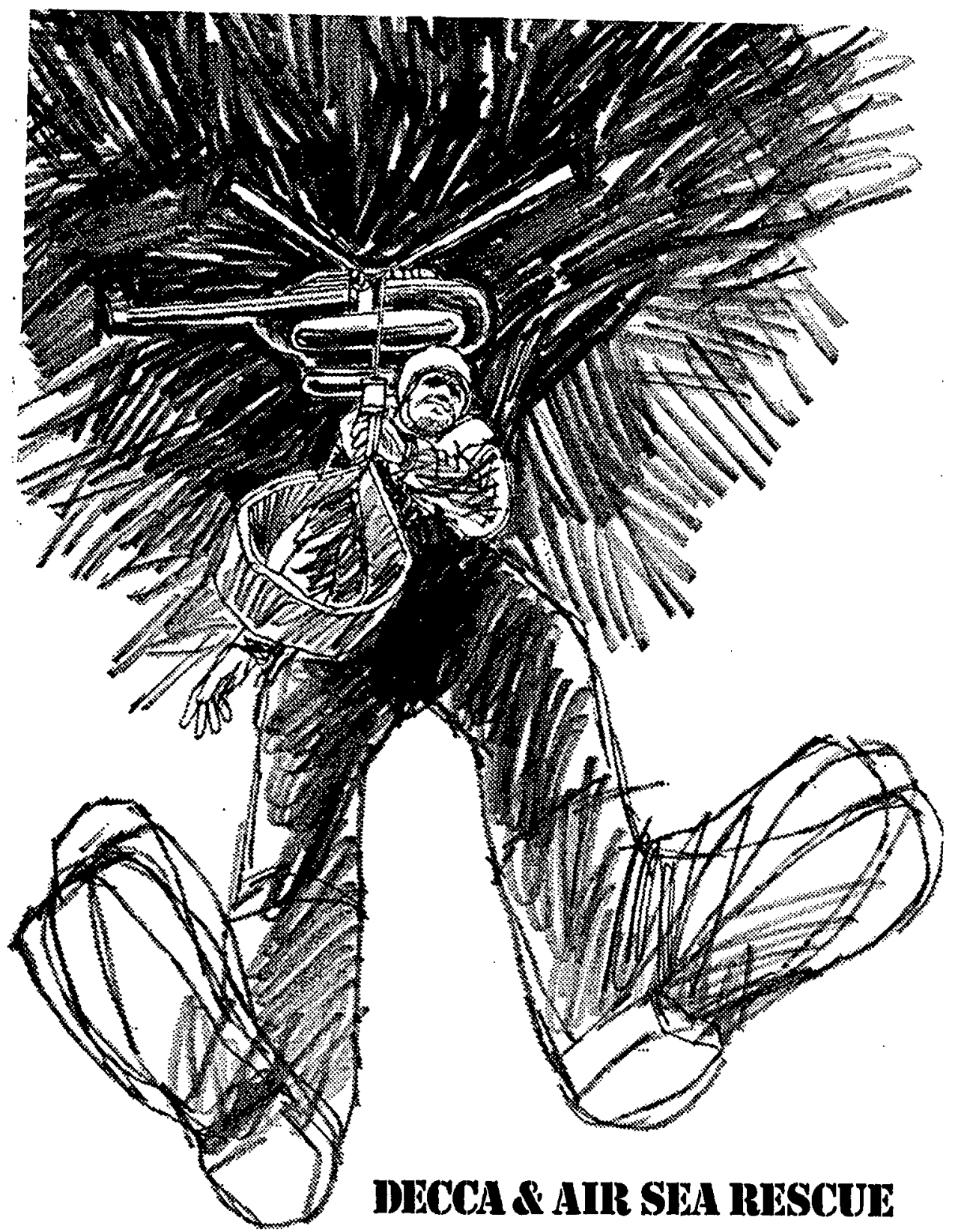

Near enough is not good enough when men's lives are at stake. That is why Decca has come to play such a vital role in modern air-sea rescue methods. Decca provides continuous high-accuracy position fixing over wide areas-enabling both ships and aircraft to use a common reference system unaffected by either altitude or weather. Air-sea rescue is only one aspect of Decca's many capabilities. For general navigation, fishing, survey and oil exploration, ships' acceptance trials, naval operations, and for the laying and maintenance of cables and buoys Decca's continuous and accurate position fixing information is relied on by over 12,000 vessels of all types and sizes. The Decca Navigator Company Limited, London 